Telle, a concert pianist whom he had met at Rochester, died unexpectedly in 2015, he lived in an assisted care Alzheimer's facility across the street from one of their two sons in San Jose. He saw his grandchildren often and still enjoyed a cup of tea or glass of wine. His family, friends, colleagues, and students will miss him dearly. \&

DOI:10.1017/rms.2017.21

Douglas Howard Calvin College

\title{
Richard L. Chambers
}

1929-2016

Richard L. Chambers was born on 27 September 1929 in Brundidge, Alabama, and died on 1 August 2016 in Montgomery, Alabama. He attended the University of Alabama, studying diplomatic and Middle Eastern history and gaining a B.A. in 1950. He obtained a B.S. in Foreign Service from Georgetown University and a fellowship at the Ludwig Maximilian University in Munich. He then pursued an M.A. in History at Alabama, graduating in 1955, just when Middle Eastern studies really began to expand nationwide. He moved to Princeton for a second master's in 1958 and a Ph.D. in 1968. He studied with Ottoman historian Lewis Thomas and wrote a dissertation on Ahmed Cevdet Paşa, the nineteenth-century Ottoman intellectual, historian, and statesman.

Professor Chambers started teaching in 1958 at the American University in Cairo, then spent two years at St. Lawrence University in Canton, New York. He became an instructor at the University of Chicago in 1962, an assistant professor in 1965, and an associate professor in 1971. Soon thereafter, promotion standards began to change, and he taught Turkish and Ottoman history and language as an associate professor until his retirement in 1995. He initiated the teaching of these subjects at Chicago and built up the Turkish studies program with a series of distinguished visiting professors, including Fahir İz and Günay Kut from Turkey. He later negotiated the hiring of the eminent Ottoman historian Halil Inalck, and after his retirement, MacArthur Fellowship awardee Cornell Fleischer. He directed Chicago's Center for Middle Eastern Studies from 1985 to 1988 and was twice Acting Director.

During his career, Richard Chambers witnessed or was involved in the foundation of almost all the main organizations in Middle Eastern and 
Turkish studies. At Princeton he held one of the early Ford Foundation fellowships for Middle Eastern studies, which were initiated in 1951. The Social Science Research Council began promoting the study of the Middle East in 1956. The NDEA Title VI centers and FLAS fellowships started operations in 1959 and the Peace Corps in 1960. 1964 saw the inauguration of the American Research Institute in Turkey (ARIT), and in 1965 Chambers received one of ARIT's early fellowships. He later held offices in that organization and was elected president in 1985; during his term he set the directions that ARIT followed for the next three decades. In 1966 a meeting of Middle East faculty held at Chicago established the Middle East Studies Association; Chambers served on several of its committees and was a candidate for president in 1984. The Turkish Studies Association (TSA, now the Ottoman and Turkish Studies Association, OTSA) was founded in 1971 with Richard Chambers as treasurer; he subsequently served on the board and chaired the prize committee. In 1982, together with Professor Ahmet Evin of Penn, he organized a summer language program for advanced Turkish at Boğaziçi University and co-directed the program until 1988. To support it, in 1985 he and several other Turkish language teachers established the AATT, American Association of Teachers of Turkish (now AATTL, Turkic Languages), and served on its board of directors. Another organization founded in 1982 was the Institute of Turkish Studies (ITS), on which he also served. Chambers had great administrative and organizational ability, and immense dedication to the work of organizations that support the study of Turkey and the Turkish language, for which he was awarded the MESA Service Award in 1998. Even before these great accomplishments, in 1977, he had already received the Education Award from the American-Turkish Council.

Professor Chambers was not a prolific author; beyond the never-published dissertation he had two edited volumes, nine articles, and some encyclopedia articles and book reviews to his name. The first of his edited volumes, however, had a huge impact on the field. It was Beginnings of Modernization in the Middle East: The Nineteenth Century, edited with William R. Polk in 1968. This book was one of the first to emphasize the contributions to modernization of Middle Eastern states and individuals, not just the West. A 1971 review by Nikki Keddie in Political Science Quarterly concluded that the volume supported a non-linear view of modernization including significant negative or "reactionary" features, such as the rigidification of the position of women and the conservatism of al-Azhar, the reinforcement of notable power and economic disparities, and the undermining of local autonomy by centralization processes. The book thus said more about twentieth and 
twenty-first century trends than its title suggested and was useful beyond its stated corner of the field.

Professor Chambers' students say about him, "He became my hoca," and "He remained an inspiration and a mentor." They call him "a man of integrity" and "one of the leaders in his field." Andras Riedlmayer said it best: "What influenced me, both then and in the long term, was his teaching, his kindness to and respect for his students, his intellectual curiosity and his knowledge of and enthusiasm for Turkish culture, which he was always glad to share."

DOI:10.1017/rms.2017.40

Linda T. Darling University of Arizona

\section{Halil İnalcık \\ 1916? - 2016}

Halil İnalcık was born in Istanbul, the capital of the Ottoman Empire, into a refugee family, probably in 1916 (he did not know his birthday; in Turkey he adopted 29 May, in the US 4 July). He died at age 100 in Ankara on 25 July 2016, as the premier Ottoman historian in the world. To quote one of his students, "Professor İnalc1k transformed the field of Ottoman studies from an obscure and exotic subfield into one of the leading historical disciplines that covers the history of the greater Middle East and North Africa as well as the Balkans from the late medieval to the modern period. He set the tone of debate and critical inquiry from the early modern to the modern period." Born an Ottoman, he made Ottoman studies a crucial part of world history.

Coming from a commercial and religious background, he graduated from teacher training college in 1935 and entered the brand-new program in history at the Dil ve Tarih-Coğrafya Fakültesi of Ankara University, studying Ottoman history with Fuad Köprülü and gaining his doctorate in 1942. Until his retirement at age 55, he remained with the faculty as a research assistant and later professor, developing the scholarly framework of Turkish national history. He was heavily influenced by Ömer Lütfi Barkan and the French Annales school of social and institutional history, and after a conference in Paris in 1950 introduced him to Braudel and his famous book, The Mediterranean and the Mediterranean World in the Age of Philip II, he 